\title{
HERMETISM VARIATION IN Camponotus morosus (Hymenoptera: Formicidae) WITH THE AGE OF HOMOSPECIFIC INTRUDING ANTS
}

\author{
Joaquín Ipinza-Regla ${ }^{1}$, Alejandra Covacevich ${ }^{1}$, Jaime E. Araya ${ }^{2 *}$ \\ ${ }^{1}$ Laboratorio de Zoología y Etología, Facultad de Ciencias, Universidad Mayor, Camino La Pirámide \\ 5750, Huechuraba, Santiago, Chile. joaquin.ipinza@umayor.cl \\ ${ }^{2}$ Facultad de Ciencias Agronómicas, Universidad de Chile, Santa Rosa 11315, La Pintana, Santiago, \\ Chile. \\ *Corresponding author E-mail: jaimearaya@yahoo.com
}

\begin{abstract}
Ants present hermetism, that is, they recognize and discriminate individuals alien to the colony, even at a homospecific level, which results in aggressive reactions against intruders, varying with their age. To evaluate the importance of this factor, transfers of homospecific larvae, pupae and 2- and 8-h-old adults of Camponotus morosus Smith were carried out. All the transferred larvae developed into pupae, and later into adults, but only $20 \%$ of these survived $15 \mathrm{~d}$ in the receiving nests. The transferred pupae were attacked and killed in $8 \mathrm{~d}$. The transfer of 2-d and 8-h old adults produced 70 and $30 \%$ acceptance, respectively. These results indicate that adults begin to develop their own odor earlier than 2-d of age. The age of the intruder was determinant in its acceptance of C. morosus homospecific resident ants, as indicated in a 1-way ANOVA $(p=0.0001)$. The adults that survived the transfer of larvae were later reintroduced into their original nests; $37.5 \%$ of them were accepted, compared with $65 \%$ acceptance for 2 - and 8 -h old adults reintroduced, indicating that there is a strong genetic influence in the development of their own smell, that would allow adults to be recognized as belonging to the nest. The fact that not all the males were accepted can be explained by the influence of the odor acquired in the receiving nest.
\end{abstract}

Key words: Ant hermetism, homospecific hermetism.

\section{INTRODUCTION}

Ants present hermetism, that is, they do not accept individuals from another nest because of their odor, due to genetic, physical, and environmental factors, or because of the particular smell of the queen (Errard et Jaisson, 1984; Hefetz et al., 1994), emitted by hydrocarbons in the epicuticle. The odor of the nest average the individual one of each ant through trophalaxis, and allows the members to discriminate, in degrees varying according to the species, between the nest ants and those intruder ants (IpinzaRegla et al., 1994). A little-studied aspect of ant hermetism is the influence of the age of the foreign ants. In Chile, Camponotus morosus Smith presents great aggressiveness, which varies with the age of these intruder ants, as it was investigated in this paper.

\section{MATERIALS AND METHODS}

Two donor and four receiving C. morosus nests containing 150 workers were used (the donor nests had a variable number of larvae and pupae), to reduce possible variations in the acceptance or rejection responses. Nests were at least $100 \mathrm{~m}$ apart to avoid interferences, and were collected in shrubs found in the pre-Andean hills in San Carlos de Apoquindo $\left(33^{\circ} 23^{\prime} 27.25^{\prime \prime}\right.$ S; 70 $\left.30^{\prime} 1.39^{\prime \prime} \mathrm{W}\right)$ and the Río Clarillo National Reserve $\left(33^{\circ} 46^{\prime} 00^{\prime \prime}\right.$ S; $\left.70^{\circ} 27^{\prime} 00^{\prime \prime} \mathrm{W}\right)$, Metropolitan Region, Santiago, Chile. These nests were taken to the Zoology and Ethology Laboratory, College of Agroforestry, Universidad Mayor, Santiago, Chile, where they were left undisturbed for acclimation, in $24 \times 34 \times$ $12 \mathrm{~cm}$ plastic containers, at $20 \pm 2^{\circ} \mathrm{C}, 45-50 \% \mathrm{RH}$, and exposed to $12 \mathrm{~h}$ light from fluorescent tubes (Cosens and Toussaint, 1985). A diet of apple 
pure mixed with bee honey and ground chicken meat (Ipinza-Regla et al., 1991) was provided; drinking water was also provided through cotton plugs. After the 3 wk acclimation, larvae, pupae, and 2 - and $8 \mathrm{~h}$-old adults from donor nests were transferred to receiving nests, where the behavior parameters were observed and registered. The resident ants were marked with color pigments to differentiate them from the arriving ants.

To carry out this study, ten larvae, pupae, 2- or 8-h-old adults were transferred separately. The receiving ants were observed $10 \mathrm{~min}$ three times a day (at 08:00, 18:00, and 00:00 h) from the first day through day 15 after egg hatching for larvae and pupae (all transfers were simultaneous). Transfers of 2- and 8-h-old adults were done as they emerged; thus, they were done in 5-12 days. Antennal examination (AE), mandible opening (MO), biting (BI), abdomen flexed dorsally (AFD), abdomen flexed ventrally (AFV), fighting (FI), isolation of the intruder (II), marginalization (MA), trophallaxis (TR), grooming (GR), transportation of the intruder (TI), indifference (IN), and death (DE) were recorded in all transfers. A male surviving the $15 \mathrm{~d}$ study was considered accepted (AC). After this period, the surviving adults were taken to their original donor nest, where the same behavior parameters were recorded during 10-min observation periods. The first appearance and frequency of each parameter were also registered.

The parameters recorded, particularly acceptance and rejection conducts were analyzed through a 1-way ANOVA to determine differences in the acceptance of the resident ants to the transfer of homospecific larvae, pupae, and 2and 8-h-old-adults. The non-parametric KruskalWallis test was used to verify the first appearance in sec of the behavior events observed when reintroducing the individuals to their original donor nest.

\section{RESULTS AND DISCUSSION}

In this study, $100 \%$ of the larvae introduced into a receiving nest were collected, transported and fed in a nest gallery by the resident workers, as also described in some previous studies (e.g.
Carlin and Hölldobler, 1983; Errard et Jaisson, 1984; Nowbahari and Lenoir, 1984; Aldea, 2001). One week after their transfer, these larvae began to pupate. All of them reached this stage in ca. 3 weeks, during which they were cared for, protected and transported; 45-60 d later, adults emerged from these pupae, which gradually began to be attacked by the resident ants, so that only $20 \%$ of these adults from introduced larvae survived the $15 \mathrm{~d}$ study in the receiving nests. The remaining $80 \%$ was killed, some hours after emergence and others in a few days; only 1, 0, 2 and 5 adults in nests 1-4, respectively, survived the entire study (Table 1 ).

After their $15 \mathrm{~d}$ survival, these adults were returned to the original nests. Their most marked behavior parameter was Antennal Exploration (AE), which occurred in all of them, with a 94 sec mean appearance period (Table 2). Mandible opening (MO) presented a $20 \%$ frequency, and occurred in 2 of the 8 reintroductions, with a $442 \mathrm{sec}$ mean appearance period. Biting (BI) appeared on average in $87 \mathrm{sec}$, with a $50 \%$ frequency. Abdomen flexed dorsally (AFD) occurred after a mean of 185 sec, only in two ants in nest 4. Abdomen flexed ventrally (AFV) occurred in a frequency of $37.5 \%$, with a $167 \mathrm{sec}$ mean.Fighting (FI) varied greatly (4 to $267 \mathrm{sec}$ ), and occurred with a frequency of $50 \%$. Trophallaxis (TR) and acceptance (AC) had both $25 \%$ frequency, with appearance periods of 278 and $225 \mathrm{sec}$, respectively. Marginalization (MA) and indifference (IN) occurred only once. Grooming occurred in 25\% of the adults. The period of appearance of IN was $525 \mathrm{sec}$, and MA was attempted since sec 2 of reintroduction, but the adults affected escaped constantly. Transportation of the intruder (TI) occurred in none of these reintroductions.

After $24 \mathrm{~h}$ reintroduction of the adults, 37.5\% was accepted, and the remaining $62.5 \%$ was killed by the original nest workers (Table 3 ).

Because of the small survival of the adults reintroduced, and the little frequency of the parameters observed, the results obtained allowed the Kruskal-Wallis test only for AE (Table $4)$, with a value of $4.752(p=1)$.

These results differ from Nowbahari and Lenoir (1989) with Cataglyphis cursor. These

Table 1. Adults surviving after $15 \mathrm{~d}$ in receiving nests from larvae transferred from donor colonies.

\begin{tabular}{cccc}
\hline Receiving nests & Emerged adults used & Adults alive after 15 d & \% survival \\
\hline 1 & 10 & 1 & 10 \\
2 & 10 & 0 & 0 \\
3 & 10 & 2 & 20 \\
4 & 10 & 5 & 50 \\
Total & 40 & 8 & 20 \\
\hline
\end{tabular}


Table 2. Behavior events observed in nests 1, 3, and 4 (no survival in nest 2), and appearance frequency $(\%)$.

\begin{tabular}{lccccc}
\hline Behavior parameters & Nest 1 & Nest 3 & Nest 4 & Means & Frequency appearing (\%) \\
\hline Antennal examination (AE) & 2 & 5 & 149 & 94 & 100.0 \\
Mandibles opening (MO) & --- & --- & 442 & 442 & 25.0 \\
Biting (BI) & 4 & --- & 144 & 87 & 50.0 \\
Abdomen flexed dorsally (AFD) & --- & --- & 185 & 185 & 25.0 \\
Abdomen flexed ventrally (AFV) & 4 & --- & 248 & 167 & 37.5 \\
Fighting (FI) & 4 & --- & 267 & 202 & 50.0 \\
Transportation of intruder (TI) & --- & --- & --- & --- & --- \\
Trophalaxis (TR) & --- & --- & 278 & 278 & 25.0 \\
Grooming (GR) & --- & 225 & --- & 225 & 25.0 \\
Indifference (IN) & --- & --- & 525 & 525 & 12.5 \\
Marginalization (MA) & --- & --- & 1 & 1 & 12.5 \\
\hline
\end{tabular}

Table 3. Survival of adults $24 \mathrm{~h}$ after reintroducing them on their original nests.

\begin{tabular}{ccc}
\hline Nests & Adults alive & \% survival \\
\hline 1 & 0 & 0.0 \\
2 & --- & -- \\
3 & 2 & 100.0 \\
4 & 1 & 37.5 \\
\hline
\end{tabular}

authors reported that all adults reintroduced were accepted in their original nests, with only minor events of aggression.

The odor pattern of ants is determined by environmental and genetic factors (Bagnéres and Morgan, 1990; Hefetz et al., 1994, 1998; Obin and Vander Meer, 1988, 1989; Boulay et al., 2000); grooming and trophalaxis, and early contact with other ants would influence greatly in mixing the individual odors of the ants in a colony and thus each member (Hefetz et al., 1994; Soroker et al., 1998; Cerdá et al., 1999; Boulay et al., 2000). The data obtained in this study leads to think that the influence of genes in C. morosus would be greater on individual odor than on environmental odor and early contact with nest workers. In fact, the adults developed from larvae transferred, accepted and taken care of up to their emergence, were killed later (after $4 \mathrm{~h}$ ). This occurred once they began to develop their own odor, as been described by Ipinza-Regla et al. (2005).

All the larvae transferred developed into pupae, and later into adults, but only $20 \%$ of these survived $15 \mathrm{~d}$ in the receiving nests. The pupae transferred were attacked and killed in 8 d. Unlike the larvae transferred, all the pupae transferred were killed. Most of these were killed by soldier ants (some of them were killed in minutes), and had a mean survival period of only $2 \mathrm{~d}$ (Table 5). Those few pupae that were not killed immediately, were transported and bitten occasionally, and then the resident ants remained indifferent.

Our results do not coincide with those reported by other authors for Cataglyphis cursor (Fonscolombe), Formica lugubris Zettersted, Camponotus vagus Scopoli, Solenopsis invicta Buren, and Pseudomyrmex ferruginae Smith, as they reported that all larvae or pupae transferred to a conspecific nest were always accepted and taken care of as belonging to the corresponding species nest (Carlin and Hölldobler, 1983; Errard et Jaisson, 1984; Nowbahari and Lenoir, 1989). It is possible that their pupae present the colony odor in the cocoons, making them recognizable and thus not attacked by their sisters, as herein.

The acceptance of 2- and 8-h-old C. morosus adults in the receiving nests is presented in Table 6.

The behavior parameters of C. morosus observed in four nests receiving 2- and 8-h-old adults from a donor nest are presented in Table 7.

The transfer of 2-d and 8-h-old adults produced 70 and $30 \%$ acceptance, respectively. These results indicate that the adults begin to develop their own odor earlier than 2-d of age. The age of the intruder was determinant in its acceptance of $C$. morosus homospecific resident ants, as indicated in a 1-way Anova $(p=0.0001)$. The adults that survived the transfer of larvae were later reintroduced into their original nests; $37.5 \%$ of them were accepted, compared with $65 \%$ acceptance for 2 - and 8 -h-old adults 
Table 4. Behavioral events $(n \pm S D)$ observed in the adults of four nests after reintroducing them on their original nests.

\begin{tabular}{|c|c|c|c|c|c|c|c|c|c|}
\hline \multirow{2}{*}{$\begin{array}{l}\text { Behavior parameters } \\
\text { Antennal examination (AE) }\end{array}$} & \multicolumn{2}{|c|}{ Nest 1} & \multicolumn{2}{|c|}{ Nest 2} & \multicolumn{2}{|c|}{ Nest 3} & \multicolumn{2}{|r|}{ Nest 4} & \multirow{2}{*}{$\frac{\text { Kruskal-Wallis }}{4.752}$} \\
\hline & 1 & 6 & 0 & --- & 2 & $5 \pm 1.4$ & 5 & $143 \pm 104.0$ & \\
\hline Mandibles opening (MO) & 1 & --- & 0 & --- & 1 & 1 & 2 & $421 \pm 166.2$ & $p=1$ \\
\hline Biting (BI) & 1 & 4 & 0 & --- & 0 & --- & 3 & $114 \pm 64.2$ & CNP \\
\hline Abdomen flexed dorsally (AFD) & 0 & --- & 0 & --- & 0 & --- & 2 & $185 \pm 113.1$ & $\mathrm{CNP}$ \\
\hline Abdomen flexed ventrally (AFV) & 1 & 4 & 0 & --- & 0 & --- & 3 & $201 \pm 119.2$ & $\mathrm{CNP}$ \\
\hline Fighting $(\mathrm{FI})$ & 1 & 4 & 0 & --- & 0 & --- & 3 & $267 \pm 112.3$ & $\mathrm{CNP}$ \\
\hline Transportation of intruder (TI) & 0 & --- & 0 & --- & 0 & $\ldots$ & 0 & --- & $\mathrm{CNP}$ \\
\hline Trofalaxis (TR) & 0 & --- & 0 & --- & 0 & $\ldots$ & 2 & $277 \pm 67.2$ & $\mathrm{CNP}$ \\
\hline Grooming (GR) & 0 & --- & 0 & --- & & $25 \pm 216.4$ & 0 & --- & $\mathrm{CNP}$ \\
\hline Indifference (IN) & 1 & 5 & 0 & --- & 0 & --- & 1 & 525 & $\mathrm{CNP}$ \\
\hline
\end{tabular}

Means \pm SD only when observed in nests 3 and 4. CNP: Calculation not possible.

Table 5. Survival of pupae $(\mathrm{d} ; \mathbf{n}=10)$ in the receiving nests.

\begin{tabular}{cc}
\hline Nests & Surviving days \\
\hline 1 & 3.3 \\
2 & 3.6 \\
3 & 2.3 \\
4 & 1.5 \\
Mean & 2.2 \\
\hline
\end{tabular}

Table 6. Acceptance of 2- and 8-h-old C. morosus adults in homospecific receiving nests.

\begin{tabular}{ccc}
\hline Nests & 2 h-old (\%) & $\mathbf{8}$ h-old (\%) \\
\hline 1 & 70 & 20 \\
2 & 60 & 30 \\
3 & 60 & 40 \\
4 & 90 & 30 \\
Means & 70 & 30 \\
\hline
\end{tabular}

reintroduced, indicating that there is a strong genetic influence in the development of their own smell, that would allow adults to be recognized as belonging to the nest, and also some influence of the environment of the smell acquired in the receiving nest, responsible for not all the males were accepted.

The acceptance of 2- and 8-h-old adults that survived in the receiving nests and were reintroduced in the donor nests are presented in Table 8. The first appearance (sec) and observation frequency of behavior parameters (\%) are shown in Table 9.

The frequencies of appearance (\%) of automarginalization, death, and acceptance of ants reintroduced after $24 \mathrm{~h}$ to their original nests from receiving nests are presented in Table 10, and the occurrence of the first appearance $(\mathrm{sec})$ of the behavior parameters observed in 2- and 8 $\mathrm{h}$ old adults after reintroduction to their original nests in Table 11.

\section{CONCLUSIONS}

A marked trend was observed in the influence of the age of the intruding ant on the level of hermetism of the resident ants. The greater the age of the intruder the more intense will be the aggressiveness and rejection of resident ants of the same species.

All the larvae transferred from donor to receiving nests were accepted and developed into pupae and later to adults. However, only $20 \%$ of these adults survived after $15 \mathrm{~d}$ in the receiving nests.

All the pupae transferred from donor to 
Table 7. Behavior parameters of 2- and 8-h-old C. morosus ants in four nests receiving 2- and 8-h-old adults from a donor nest.

\begin{tabular}{cl}
\hline 2 h-old & \multicolumn{1}{c}{ Behavior parameters observed } \\
\hline & Nest 1 \\
1 & AE, BI, AFV, FI, death before the end of the day \\
2 & AE, BI, AFV, FI, death before the end of the day \\
3 & AE, MO, AFD, TI, BI sporadic, FI with 2 workers, death at the end of the day \\
4 & AE frequent, MO, BI sporadic, IN \\
5 & AE, TI \\
6 & AE, TI \\
7 & AE frequent, BI sporadic \\
8 & AE frequent, BI, MO \\
9 & AE, IN \\
10 & AE, MO, IN
\end{tabular}

\section{Nest 2}

$1 \mathrm{AE}, \mathrm{MO}, \mathrm{BI}, \mathrm{AFD}, \mathrm{AFV}, \mathrm{FI}$, death before the end of the day

$\mathrm{AE}$ frequent, $\mathrm{MO}, \mathrm{BI}$ sporadic, death before the end of the day

$\mathrm{AE}$ frequent, MA, BI, IN, death before the end of the day

$\mathrm{BI}, \mathrm{AE}$ frequent, death before the end of the day

$\mathrm{BI}, \mathrm{AE}$ frequent

EA, BI sporadic, IN

EA, BI sporadic, IN

EA, IN

IN

EA, TI

\section{Nest 3}

$\mathrm{AE}, \mathrm{MO}, \mathrm{BI}, \mathrm{AFD}, \mathrm{AFV}, \mathrm{FI}$, death before the end of the day

Death

Death

Acceptance

Acceptance

Acceptance

Acceptance

Acceptance

Acceptance

Acceptance

$\mathrm{MO}, \mathrm{BI}, \mathrm{AFD}, \mathrm{AFV}$, death before the end of the day

Death

Death

Death

Death

Acceptance

Acceptance

Acceptance

Acceptance

Acceptance

Acceptance

$\mathrm{BI}, \mathrm{AFV}, \mathrm{FI}$, death before the end of the day

Death

Death

Death

$\mathrm{BI}, \mathrm{AFV}, \mathrm{FI}$, death before the end of the day

Death

AE frequent, BI sporadic, IN

IN

$\mathrm{AE}, \mathrm{IN}$

$\mathrm{AE}, \mathrm{IN}$

$\mathrm{AE}, \mathrm{IN}$

$\mathrm{AE}, \mathrm{IN}$

Nest 4

Acceptance

Acceptance

Acceptance

Acceptance

Acceptance

Acceptance

$\mathrm{MO}, \mathrm{AFD}$, death before the end of the day

Death

$\mathrm{AE}, \mathrm{MO}$ sporadic

AE, IN, MO sporadic

Acceptance

$\mathrm{AE}, \mathrm{MO}, \mathrm{IN}$

Acceptance

Acceptance

AE, OM, IN, BI sporadic

Acceptance

$\mathrm{EA}, \mathrm{MO}, \mathrm{BI}$

Acceptance

EA, TI

EA, MO, IN

EA, MO, BI, IN

Acceptance

Acceptance

EA, TI

Acceptance

Acceptance

\begin{tabular}{cl}
\hline 8 h-old & \multicolumn{1}{c}{ Behavior parameters observ } \\
\hline & AE, MO, BI, marginalization during 3 d \\
2 & AE, MO, BI, FI, death before the end of the day \\
3 & AE, MO, BI, FI, death before the end of the day \\
4 & BI, AFD, AFV, FI, death before the end of the day \\
5 & AE, MO, BI, TI \\
6 & AE, MO, BI, TI \\
7 & AE, MO, BI sporadic, FI, death before the end of the day
\end{tabular}

Final results

Death

Death

Death

Death

Death

Death

Death 


\section{Nest 2}

FI, death before the end of the day

$\mathrm{FI}$, death before the end of the day

$\mathrm{AE}, \mathrm{MO}, \mathrm{BI}, \mathrm{TI}$

$\mathrm{AE}$, TI constantly to the honey

$\mathrm{AE}, \mathrm{TI}$

$\mathrm{AE}, \mathrm{MO}, \mathrm{BI}, \mathrm{TI}$, death before the end of the day

$\mathrm{AE}, \mathrm{BI}, \mathrm{MO}, \mathrm{IN}$

$\mathrm{AE}, \mathrm{BI}, \mathrm{MO}, \mathrm{IN}$

AE, MO, BI, DFA, VFA, FI

$\mathrm{AE}, \mathrm{MO}, \mathrm{TI}$, death and following day

\section{Nest 3}

$\mathrm{AE}, \mathrm{MO}, \mathrm{BI}, \mathrm{AFD}, \mathrm{AFV}, \mathrm{FI}$, death before the end of the day

$\mathrm{AE}, \mathrm{BI}, \mathrm{AFD}, \mathrm{AFV}, \mathrm{FI}$, death before the end of the day

\section{$\mathrm{MO}$}

$\mathrm{AE}, \mathrm{BI}, \mathrm{TI}$

AE, BI, IN

$\mathrm{AE}, \mathrm{MO}, \mathrm{BI}$ sporadic, TI

AE, MO, BI sporadic, TI

$\mathrm{AE}, \mathrm{MO}, \mathrm{BI}, \mathrm{DFA}, \mathrm{TI}$

BI sporadic

IN

\section{Nest 4}

$\mathrm{BI}, \mathrm{FI}$, death before the end of the day

$\mathrm{BI}, \mathrm{FI}$, death before the end of the day

Acceptance

$\mathrm{AE}, \mathrm{MO}, \mathrm{BI}, \mathrm{MO}, \mathrm{AFD}, \mathrm{AFV}, \mathrm{FI}$, death before the end of the day

Death

Death

Death

Death

Acceptance

Death

Acceptance

Acceptance

Death

Death

$\mathrm{AE}, \mathrm{AM}$, marginalization, $\mathrm{BI}$, death before the end of the day

Death

Death

Death

Death

Acceptance

Death

Acceptance

Death

Acceptance

Acceptance

$\mathrm{AE}, \mathrm{BI}, \mathrm{MO}$, death before the end of the day

Death

Death

Death

Death

$\mathrm{AE}, \mathrm{IN}, \mathrm{FI}$, death before the end of the day

Death

$\mathrm{AE}, \mathrm{IN}$

AE, BI, IN

Death

AE, BI, IN

Acceptance

Death

$\mathrm{AE}, \mathrm{IN}$

Acceptance

AE: Antennal examination; MO: Mandibles opening; BI: Biting; AFD: Abdomen flexed dorsally; AFV: Abdomen flexed ventrally; FI: Fighting; TI: Transportation of intruder; IN: Indifference.

Table 8. Acceptance of 2- and 8-h-old adults that survive in the receiving nests and were reintroduced at the donor nests.

\begin{tabular}{cccc}
\hline Nests & 2 h-old & $\mathbf{8}$ h-old & Total \\
\hline 1 & 70 & 20 & 9 \\
2 & 60 & 30 & 9 \\
3 & 60 & 40 & 10 \\
4 & 90 & 30 & 12 \\
Total & 28 & 12 & 40 \\
\hline
\end{tabular}


Table 9. First appearance (sec) and observation frequency of behavior parameters (\%) after reintroducing 2- and 8-h-old adults to their original nests from their receiving nests.

\begin{tabular}{lcccccc}
\hline Parameters & Nest $\mathbf{1}$ & Nest $\mathbf{2}$ & Nest $\mathbf{3}$ & Nest $\mathbf{4}$ & Means & Frequency (\%) \\
\hline AE & 59 & 25 & 25 & 13 & 36 & 92.5 \\
MO & 15 & 43 & 138 & 15 & 17 & 42.5 \\
BI & 80 & 73 & 53 & 81 & 75 & 47.5 \\
AFD & 149 & --- & --- & 22 & 64 & 7.5 \\
AFV & 139 & 119 & --- & 143 & 138 & 35.0 \\
FI & 157 & 170 & 119 & 32 & 164 & 45.0 \\
TI & --- & 2 & --- & --- & 2 & 2.5 \\
TR & --- & 198 & 204 & 150 & 194 & 15.0 \\
GR & --- & 125 & 241 & --- & 195 & 12.5 \\
IN & 162 & 129 & 113 & 43 & 111 & 27.5 \\
\hline
\end{tabular}

AE: Antennal exploration; MO: Mandibles opening; BI: Biting; AFD: Abdomen flexed dorsally; AFV: Abdomen flexed ventrally; FI: Fighting; TI: Transportation of intruder; TR: Trophalaxis; GR: Grooming; IN: Indifference.

Table 10. Frequencies of appearance (\%) of automarginalization, death, and acceptance of ants reintroduced after $24 \mathrm{~h}$ to their original nests from receiving nests.

\begin{tabular}{lccccc}
\hline Parameters & Nest $\mathbf{1}$ & Nest 2 & Nest 3 & Nest 4 & Means \\
\hline Automarginalization & 0.0 & 11.1 & 20.0 & 0.0 & 7.5 \\
Death & 66.7 & 33.3 & 0.0 & 41.7 & 35.0 \\
Acceptance & 33.3 & 66.7 & 100.0 & 58.3 & 65.0
\end{tabular}

Table 11. Comparison of the first appearance (sec) of the behavior parameters observed in 2- and 8-h-old adults after reintroduction to their original nests.

\begin{tabular}{|c|c|c|c|c|c|}
\hline Parameters & Nest $1^{1}$ & Nest $2^{1}$ & Nest $3^{1}$ & Nest $4^{1}$ & $\mathrm{KW}^{2}$ \\
\hline $\mathrm{AE}$ & $\begin{array}{c}n=8 \\
59 \pm 123.9\end{array}$ & $\begin{array}{c}n=9 \\
25 \pm 21.3\end{array}$ & $\begin{array}{c}\mathrm{n}=10 \\
25 \pm 21.7\end{array}$ & $\begin{array}{c}\mathrm{n}=11 \\
12 \pm 5.0\end{array}$ & $\begin{array}{c}1.299 \\
p=0.73\end{array}$ \\
\hline $\mathrm{MO}$ & $\begin{array}{c}\mathrm{n}=5 \\
15 \pm 7.3\end{array}$ & $\begin{array}{c}n=3 \\
43 \pm 32.3\end{array}$ & $\begin{array}{c}n=2 \\
137 \pm 102.5\end{array}$ & $\begin{array}{c}\mathrm{n}=7 \\
15 \pm 1.4\end{array}$ & $\begin{array}{c}10.011 \\
p=0.04^{*}\end{array}$ \\
\hline BI & $\begin{array}{c}n=7 \\
80 \pm 95.2\end{array}$ & $\begin{array}{c}n=2 \\
72 \pm 53.0\end{array}$ & $\begin{array}{c}n=3 \\
53 \pm 37.1\end{array}$ & $\begin{array}{c}n=7 \\
80 \pm 102.3\end{array}$ & $\begin{array}{c}0.4881 \\
p=0.92\end{array}$ \\
\hline AFD & $\begin{array}{c}n=1 \\
149 \pm--\end{array}$ & $\begin{array}{c}n=0 \\
-- \pm---\end{array}$ & $\begin{array}{c}n=0 \\
-- \pm---\end{array}$ & $\begin{array}{c}n=2 \\
22 \pm 1.4\end{array}$ & $\begin{array}{l}\text { Calculation } \\
\text { not possible }\end{array}$ \\
\hline $\mathrm{AFV}$ & $\begin{array}{c}n=6 \\
139 \pm 132.8\end{array}$ & $\begin{array}{c}\mathrm{n}=2 \\
119 \pm 4.2\end{array}$ & $\begin{array}{c}n=0 \\
-- \pm---\end{array}$ & $\begin{array}{c}n=6 \\
143 \pm 154.6\end{array}$ & $\begin{array}{c}0.2529 \\
p=0.89\end{array}$ \\
\hline FI & $\begin{array}{c}n=7 \\
157 \pm 136.3\end{array}$ & $\begin{array}{c}n=3 \\
170 \pm 86.7\end{array}$ & $\begin{array}{c}n=1 \\
119 \pm---\end{array}$ & $\begin{array}{c}n=7 \\
32 \pm 163.9\end{array}$ & $\begin{array}{c}0.25 \\
p=0.97\end{array}$ \\
\hline TI & $\begin{array}{c}n=0 \\
-- \pm---\end{array}$ & $\begin{array}{l}n=1 \\
2 \pm---\end{array}$ & $\begin{array}{c}n=0 \\
-- \pm---\end{array}$ & $\begin{array}{c}n=0 \\
-- \pm---\end{array}$ & $\begin{array}{l}\text { Calculation } \\
\text { not possible }\end{array}$ \\
\hline TR & $\begin{array}{c}n=0 \\
--- \pm--\end{array}$ & $\begin{array}{c}n=1 \\
198 \pm---\end{array}$ & $\begin{array}{c}n=4 \\
204 \pm 113.1\end{array}$ & $\begin{array}{c}n=1 \\
150 \pm---\end{array}$ & $\begin{array}{c}0.149 \\
p=1.00\end{array}$ \\
\hline GR & $\begin{array}{c}n=0 \\
-- \pm---\end{array}$ & $\begin{array}{c}n=2 \\
125 \pm 56.6\end{array}$ & $\begin{array}{c}n=3 \\
241 \pm 179.6\end{array}$ & $\begin{array}{c}n=0 \\
--- \pm---\end{array}$ & $\begin{array}{c}2.00 \\
p=0.8\end{array}$ \\
\hline IN & $\begin{array}{c}n=3 \\
163 \pm 233.1\end{array}$ & $\begin{array}{c}n=3 \\
129 \pm 85.7\end{array}$ & $\begin{array}{c}n=2 \\
112 \pm 7.5\end{array}$ & $\begin{array}{c}n=3 \\
43 \pm 63.4\end{array}$ & $\begin{array}{c}0.25 \\
p=0.89\end{array}$ \\
\hline
\end{tabular}

${ }^{1}$ Means \pm SD. ${ }^{2}$ Test of Kruskal-Wallis. AE: Antennal exploration; MO: Mandibles opening; BI: Biting; AFD: Abdomen flexed dorsally; AFV: Abdomen flexed ventrally; FI: Fighting; TI: Transportation of intruder; TR: Trophalaxis; GR: Grooming; IN: Indifference. 
receiving nests were killed in $3 \mathrm{~d}$ on average, possibly because they smelt to their original colony, and were recognized as alien and attacked by the receiving ants.

$70 \%$ of the $8 \mathrm{~h}$ old adults transferred from donor to receiving nests were killed. Accordingly, 2 -d old adults presented only 30\% mortality, possibly because they begin to develop their own odor earlier than $2 \mathrm{~h}$. Because of the same reason, the 2- and 8-h-old adults developed from larvae transferred and then reintroduced to their original nests were accepted in 37.5 and $65.0 \%$, respectively.

\section{ACKNOWLEDGMENTS}

The authors thank the support of the Fund for Research and Development (FIDUM), Universidad Mayor.

\section{LITERATURE CITED}

Aldea, P. 2001. Hermetismo entre Camponotus chilensis Spinola 1851 and Camponotus morosus Smith 1858 (Hymenoptera: Formicidae). Memoria Médico Veterinario. Facultad de Ciencias Silvoagropecuarias, Universidad Mayor, Santiago, Chile.

Bagnéres, A.G., and E.G. Morgan. 1990. The postpharyngeal glands on the cuticle of Formicidae contain the same characteristic hydrocarbons. Experientia 47:106-111.

Boulay, R., A. Heffetz, A. Lenoir, and V. Soroker. 2000. Camponotus fellah colony integration: worker individuality necessitates frequent hydrocarbon exchanges. Animal Behaviour 59:1127-1133.

Carlin, N.F., and B. Hölldobler. 1983. Nestmate and kin recognition in interspecific mixed colonies of ants. Science 222(4627):1027-1029.

Cerdá, X., A. Dahbi, A. Hefetz, and A. Lenoir. 1999. Trophalaxis mediates uniformity of colony odor in Cataglyphis iberica ant (Hymenoptera: Formicidae). Journal of Insect Behavior 12(4):557-567.

Cosens, D., and N. Toussaint. 1985. An experimental study of the foraging strategy of the wood ant Formica aquilonia. Animal Behaviour 33:541-552.

Errard, C., et P. Jaisson.1984. Études des relation sociaux dans les colonies mistes hétéroespécifiques chez les fourmis. Folia Entomológica Mexicana 61:135-146.

Hefetz, A., D. Fresneau, and V. Soroker.1998. Formation of colony odor in ponerine ant Pachycondyla apicalis. Journal of Chemical Ecology 24(6):1077-1090.
Hefetz, A., E. Nowbahari, V. Soroker, and C. Vienne. 1994. The postpharyngeal gland as a "Gestalt" organ for nestmate recognition in the ant Cataglyphis niger. Naturwissenschaften 81:510-513.

Ipinza-Regla, J., C. Carbonell, y M.A. Morales. 1994. Hermetismo en sociedades mixtas de hormigas (Hymenoptera: Formicidae) en nidos artificiales. Revista Chilena de Entomología 21:41-45.

Ipinza-Regla, J., A. Fernández, y M. Morales. 2005. Hermetismo entre Solenopsis gayi Spinola, 1981 y Brachymyrmex giardii Emery, 1894. Gayana 69(1):27-35.

Ipinza-Regla, J., A. Lucero, y M.A. Morales. 1991. Hermetismo en sociedades de Camponotus morosus Smith, 1858 (Hymenoptera: Formicidae) en nidos artificiales. Revista Chilena de Entomología 19:29-38.

Nowbahari, E., and A. Lenoir. 1984. Nest separation and the dynamics of the Gestalt odor in the polydomous ant Cataglyphis iberica (Hymenoptera: Formicidae). Behavioral Ecology and Sociobiology 42(5):349-355.

Nowbahari, E., and A. Lenoir. 1989. Age related changes in aggression in ant Cataglyphis cursor (Hymenoptera: Formicidae): Influence of intercolonial relationships. Behavioral Processes 18:173-181.

Obin, M., and R.K. Vander Meer. 1988. Sources of nestmate recognition cues on the imported and Solenopsis invicta Buren (Hymenoptera: Formicidae). Animal Behavior 36:1361-1370.

Obin, M., and R.K. Vander Meer. 1989. Betweenspecies and within-species recognition among imported fire ants and their hybrids (Hymenoptera: Formicidae) - application to hybrid zone dynamics. Annals Entomological Society of America 82:649-652.

Soroker, V., D. Fresneau, and A. Hefetz. 1998. Formation of colony odor in ponerine ant Pachycondyla apicalis. Journal of Chemical Ecology 24(6):1077-1090. 